
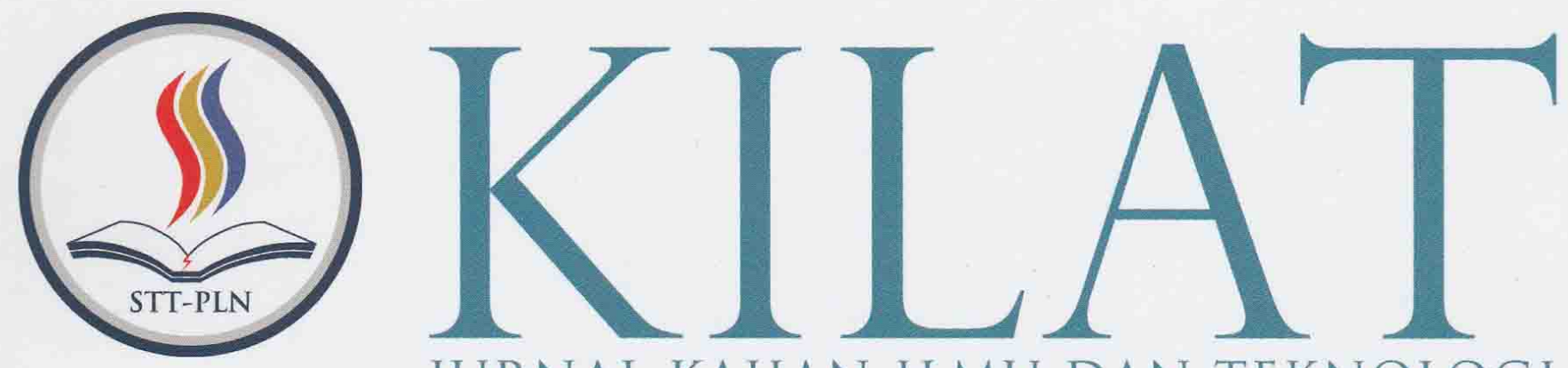
JURNAL KAJIAN ILMU DAN TEKNOLOGI

Dine Tiara Kusuma:

M. Yoga Distra Sudirman: Yessy Fitriani

Emillia; Yuliansyah

Rosida Nur Aziza; Dhzillan Dzhalila

Ranti Hidayawanti

Dewi Arianti Wulandari; Hendra Jatnika; Yudhy S. Purwanto

Rr. Mekar Ageng Kinasti; Endah Lestari; Devita Mayasari

Faisal Piliang

Mauludi Manfaluthy

Pauzi Hasan; Peby Wahyu Purnawan

Rahmi Amir: Baginda Oloan Lubis

Sabar Hanadwiputra; Subandri

Ndaru Ruseno; Satria
PENDEKATAN METODE ALTMAN Z-SCORE DALAM PENENTUAN INSENTIF BONUS PEGAWAI

METODE YURIDIS PENGELOLAAN SAMPAH RUMAH TANGGA DAN SAMPAH SEJENIS DI STT-PLN

METODE KUANTITATIF DENGAN PENDEKATAN KLASIK PADA APLIKASI ANALISIS BUTIR SOAL SEBAGAI MEDIA EVALUASI PENENTUAN SOAL YANG BERKUALITAS

UPAYA TERTIB LISTRIK TERHADAP INSTALATIR KABEL DI DAERAH PADAT PENDUDUK (STUDY KASUS KEC. TAMBORA)

RANCANG BANGUN APLIKASI CLUSTERING DATA MINING MENGGUNAKAN METODE K-MEANS DAN K-MODES

POTENSI PEMANFAATAN LIMBAH PEMBAKARAN BATUBARA (BOTTOM ASH) PADA PLTU SEBAGAI MEDIA TANAM DALAM UPAYA MENGURANGI PENCEMARAN LINGKUNGAN

PEMILIHAN PERANGKAT LUNAK PEMINDAHAN BERKAS DALAM MENINGKATKAN PEMANFAATAN TELEPON PINTAR

PEMANFAATAN RADIASI ENERGI TEGANGAN 150 KV UNTUK LAMPU LED PENERANGAN JALAN

KAJIAN PERBANDINGAN PERFORMANSI ROUTING PROTOCOL RIPNG, OSPFV3 DAN EIGRPVG PADA JARINGAN IPV6

PERANCANGAN PROGRAM PENGELOLAAN DATA KEUANGAN PASIEN RAWAT JALAN BPJS PADA RUMAH SAKIT GRAHA JUANDA BEKASI

ANALISA DAN IMPLEMENTASI VTP DENGAN ETHERCHANNEL TYPE LACP

PENGEMBANGAN RANCANG BANGUN SISTEM KESISWAAN DENGAN MENGGUNAKAN FRAMEWORK MVC

(MODEL VIEW CONTROLLER)

\begin{tabular}{|l|l|l|l|l|l|}
\hline KILAT & VOL.7 & NO.1 & HAL. 1 - 90 & APRIL 2018 & ISSN 2089 - 1245 \\
\hline
\end{tabular}




\title{
RANCANG BANGUN APLIKASI CLUSTERING DATA MINING MENGGUNAKAN METODE K-MEANS DAN K-MODES
}

\author{
Dewi Arianti Wulandari; Hendra Jatnika; Yudhy S. Purwanto \\ Jurusan Teknik Informatika \\ Sekolah Tinggi Teknik PLN Jakarta \\ Email : dewiarianti@sttpln.ac.id
}

\begin{abstract}
Strategies and policies in a profit-oriented organization also have a social mission (public service) that prioritizes the service to the customer. The development of information system and information technology will impact on a competitive competition. This development also applies in the world of certification that requires the manager to build and develop information system to help the business activities, to achieve organizational goals and services for stakeholders, especially those which related to data, information, technology and application. We found some cases of information system management failure in achieving organizational objectives because the utilization is not in accordance with the direction and objectives of the organization. The system will analyze the relationship pattern of goods towards the goods order based on needs and usage. Furthermore, the patterns will be recognized so that we can obtain the composition set of criteria to order the goods. To find the patterns and information from a collection of reservation data into a decision-making material. Therefore, the writers make a study with the title "Implementation of K-Means and K-Modes Methods in Clustering Data Mining in Determining the Textile Material Ordering Set" (Case Study: UD. HO KIKU)
\end{abstract}

Keywords: K-Means, Information Systems, K-Modes, Clustering Data Mining

\begin{abstract}
Abstrak
Strategi dan kebijakan dalam suatu organisasi yang profit oriented juga mempunyai misi sosial (public service) yang mengutamakan pada layanan konsumen. Perkembangan sistem informasi dan teknologi informasi akan berdampak pada persaingan yang semakin kompetitif. Hal ini berlaku juga di dunia seretifikasi menuntut pihak pengelola untuk membangun dan mengembangkan sistem informasi dalam membantu aktifitas bisnis, mencapai tujuan organisasi dan layanan bagi stakeholder terutama yang berhubungan dengan data, informasi, teknologi dan aplikasi. Telah ditemukan beberapa kasus pengelolaan sistem informasi yang mengalami kegagalan dalam mencapai tujuan organisasi karena pemanfaatan ini tidak sesuai dengan arah dan tujuan organisasi. Sistem yang akan dibuat ini akan menganalisa pola hubungan barang terhadap pemesanan berdasarkan kebutuhan dan pemakaian. Selanjutnya akan dikenali pola-pola tersebut sehingga bisa didapatkan komposisi himpunan kriteria untuk pemesanan barang. Untuk menemukan pola-pola dan informasi dari sekumpulan koleksi data pemesanan menjadi bahan pengambilan keputusan. Oleh karena itu penulis membuat penelitian dengan judul "Rancang Bangun Aplikasi Clustering Data Mining Menggunakan Metode K-Means dan K-Modes."
\end{abstract}

Kata Kunci: K-Means, Sistem Informasi, K-Modes, Clustering Data Mining

\section{PENDAHULUAN}

Data mining adalah suatu konsep yang digunakan untuk menemukan pengetahuan yang tersembunyi di dalam database. Data mining merupakan proses semi otomatik yang menggunakan teknik statistik, matematika, kecerdasan buatan, dan machine learning untuk mengekstraksi dan mengidentifikasi informasi pengetahuan potensial dan berguna yang tersimpan di dalam database besar. Kehadiran data mining dilatarbelakangi oleh berlimpahnya data (overload data) yang dialami oleh berbagai institusi, perusahaan atau organisasi. Berlimpahnya data ini merupakan akumulasi data transaksi yang terekam bertahun-tahun. Menurut Connolly (2005, p1115) Data minning adalah proses menemukan informasi yang benar, belum diketahui sebelumnya, dapat dipahami dan dapat berguna dari basis data yang besar serta dapat mendukung keputusan penting.

Sistem yang akan dibuat ini akan menganalisa pola hubungan barang terhadap pemesanan berdasarkan kebutuhan dan pemakaian. Selanjutnya akan dikenali pola-pola tersebut sehingga bisa didapatkan komposisi himpunan kriteria untuk pemesanan barang. Untuk menemukan pola-pola dan informasi dari sekumpulan koleksi data pemesanan menjadi bahan pengambilan keputusan. Oleh karena itu, penulis membuat penelitian dengan judul "Rancang Bangun Aplikasi Clustering Data Mining Menggunakan Metode K-Means dan K-Modes."

Dari latar belakang di atas dapat dibuat menjadi beberapa rumusan masalah sebagai berikut: 
1. Bagaimana menerapkan metode clustering $K$ Means dan K-Modes dalam proses pengelompokkan data?

2. Bagaimana metode K-Means dan K-Modes dapat membantu pengambilan keputusan?

\section{METODOLOGI PENELITIAN}

\section{a. Metode Clustering Pada Data Mining}

Dengan definisi data mining yang luas, ada banyak jenis metode analisis yang dapat digolongkan dalam data mining.

Clustering termasuk metode yang sudah cukup dikenal dan banyak dipakai dalam data mining. Sampai sekarang para ilmuwan dalam bidang data mining masih melakukan berbagai usaha untuk melakukan perbaikan model clustering karena metode yang dikembangkan sekarang masih bersifat heuristic. Usaha-usaha untuk menghitung jumlah cluster yang optimal dan pengklasteran yang paling baik masih terus dilakukan. Dengan demikian menggunakan metode yang sekarang, tidak bisa menjamin hasil pengklasteran sudah merupakan hasil yang optimal. Namun, hasil yang dicapai biasanya sudah cukup bagus dari segi praktis.

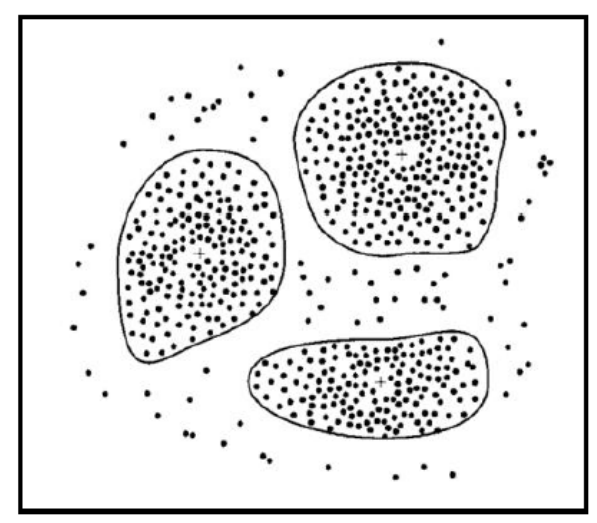

\section{Gambar 1. Clustering}

Tujuan utama dari metode clustering adalah pengelompokan sejumlah data/obyek ke dalam cluster (group) sehingga dalam setiap cluster akan berisi data yang semirip mungkin seperti diilustrasikan pada gambar 2.1. Dalam clustering metode ini berusaha untuk menempatkan obyek yang mirip (jaraknya dekat) dalam satu klaster dan membuat jarak antar klaster sejauh mungkin. Ini berarti obyek dalam satu cluster sangat mirip satu sama lain dan berbeda dengan obyek dalam cluster-cluster yang lain. Dalam metode ini tidak diketahui sebelumnya berapa jumlah cluster dan bagaimana pengelompokannya.

\section{b. Macam Model Clustering}

Yudi Agusta dalam jurnalnya menjelaskan data clustering merupakan salah satu metode data mining yang bersifat tanpa arahan (unsupervised). Ada dua jenis data clustering yang sering dipergunakan dalam proses pengelompokan data, yaitu hierarchical (hirarki) data clustering dan nonhierarchical (non-hirarki) data clustering. Fuzzy clustering merupakan salah satu metode data clustering non hirarki yang berusaha mempartisi data yang ada ke dalam bentuk satu atau lebih cluster/kelompok. Metode ini mempartisi data ke dalam cluster/kelompok sehingga data yang memiliki karakteristik yang sama dikelompokkan ke dalam satu cluster yang sama dan data yang mempunyai karakteristik yang berbeda dikelompokkan ke dalam kelompok yang lain.

Adapun tujuan dari data clustering ini adalah untuk meminimalisasikan objective function yang diset dalam proses clustering, yang pada umumnya berusaha meminimalisasikan variasi di dalam suatu cluster dan memaksimalisasikan variasi antar cluster.

Secara garis besar ada beberapa kategori algoritma clustering yang dikenal, yaitu salah satunya adalah metode partisi, dimana pemakai harus menentukan jumlah $\mathrm{k}$ partisi yang diinginkan lalu setiap data dites untuk dimasukkan pada salah satu partisi sehingga tidak ada data yang overlap dan satu data hanya memiliki satu cluster. Contohnya adalah Algoritma K-Means.

\section{1). Algoritma K-Means}

Algoritma K-Means merupakan satu algoritma yang mudah dan kerap digunakan di dalam teknik pengelompokan karena ia melibatkan pengiraan yang efisien dan tidak memerlukan banyak parameter. K-Means menggunakan $k$ kelompok yang telah ditetapkan (k kelompok pertama sebagai centroid) dan secara berterusan akan melalui proses pengiraan titik tengah (min) sehingga sesuatu fungsi kriteria dicapai (kelompok adalah tetap). Di dalam teknik pengelompokan, pengiraan untuk membedakan di antara kelompok dilakukan menggunakan satu algoritma yang dipanggil fungsi jarak yaitu tahap persamaan atau perbedaan.

Langkah-langkah algoritma K-means adalah sebagai berikut:

1. Tentukan nilai $\mathrm{k}$ sebagai jumlah klaster yang ingin dibentuk.

2. Bangkitkan k centroid (titik pusat klaster) awal secara random.

3. Hitung jarak setiap data ke masing-masing centroid menggunakan rumus korelasi antar dua objek, yaitu Euclidean Distance.

4. Kelompokkan setiap data berdasarkan jarak terdekat antara data dengan centroid-nya.

5. Tentukan posisi centroid baru $\left(\mathrm{C}_{k}\right)$ dengan cara menghitung nilai rata-rata dari data-data yang ada pada centroid yang sama.

$$
C_{k}=\left(\frac{1}{n_{k}}\right) \sum d_{i}
$$

Dimana $\mathrm{n}_{\mathrm{k}}$ adalah jumlah dokumen dalam cluster $\mathrm{k}$ dan $\mathrm{d}_{\mathrm{i}}$ adalah dokumen dalam cluster $\mathrm{k}$.

6. Kembali ke langkah 3 jika raiso antara BCV (Between Cluster Variation) dan WCV (Within Cluster Variation) membesar.

$\mathrm{BCV}=\mathrm{d}\left(\mathrm{m}_{1}, \mathrm{~m}_{2}\right)+\mathrm{d}\left(\mathrm{m}_{1}, \mathrm{~m}_{3}\right)+\mathrm{d}\left(\mathrm{m}_{2}, \mathrm{~m}_{3}\right)$, dalam hal ini $d\left(m_{i}, m_{j}\right)$ menyatakan jarak Euclides dari $\mathrm{m}_{\mathrm{i}}$ ke $\mathrm{m}_{\mathrm{j}}$.

$\mathrm{WCV}=$ jumlah kuadrat dari masing-masing jarak pusat terdekat. 
Adapun karakteristik dari algoritma K-Means salah satunya adalah sangat sensitif dalam penentuan titik pusat awal klaster karena K-Means membangkitkan titik pusat klaster awal secara random. Pada saat pembangkitan awal titik pusat yang random tersebut mendekati solusi akhir pusat klaster, K-Means mempunyai posibilitas yang tinggi untuk menemukan titik pusat klaster yang tepat. Sebaliknya, jika awal titik pusat tersebut jauh dari solusi akhir pusat klaster, maka besar kemungkinan ini menyebabkan hasil pengklasteran yang tidak tepat. Akibatnya K-Means tidak menjamin hasil pengklasteran yang unik. Inilah yang menyebabkan metode K-Means sulit untuk mencapai optimum global, akan tetapi hanya minimum lokal. Selain itu, algoritma K-Means hanya bisa digunakan untuk data yang atributnya bernilai numeric.

Pengukuran persamaan atau jarak merupakan tugas yang penting di dalam proses analisa kelompok di mana hampir semua teknik pengelompokan menggunakan pengiraan matriks jarak (atau perbedaan). Algoritma K-Means juga menggunakan kaedah pengiraan ini bagi menjelaskan lagi persamaan bagi setiap corak kelompok. Matriks Jarak Euclidean merupakan salah satu matriks jarak yang sering digunakan di dalam algoritma K-Means.

$$
\begin{aligned}
& d_{\text {Euclidean }}(x, y)=\sqrt{\sum_{i=1}^{n}\left(x_{i}-y_{i}\right)^{2}} \\
& \text { Jarak Euclidean } \\
& \begin{array}{ll}
\mathrm{d}(\mathrm{x}, \mathrm{y}) & =\text { jarak di antara } \mathrm{x} \text { dan } \mathrm{y} \\
\mathrm{y}_{\mathrm{i}} & =\text { nilai pembolehubah i bagi } \mathrm{x} \\
\mathrm{x}_{\mathrm{i}} & =\text { nilai pembolehubah i bagi } \mathrm{y}
\end{array}
\end{aligned}
$$

\section{2). Algoritma K-Modes}

Metode K-Means hanya dapat bekerja dengan baik untuk set data yang tipe data fiturnya numeric (interval atau rasio), namun tidak dapat digunakan untuk fitur kategorikal (nominal atau ordinal). Untuk menyelesaikan masalah tersebut, K-Modes melakukan modifikasi pada K-Means sebagai berikut:
1. Menggunakan
ukuran pencocokan ketidakmiripan sederhana pada fitur data bertipe kategorikal.

2. Mengganti mean cluster dengan modus (nilai yang paling sering muncul).

3. Menggunakan metode berbasis frekuensi unuk mencari modus dari sekumpulan nilai. Langkah-langkah algoritma K-Modes adalah sebagai berikut:

1. Tahap pertama pilih inisialisasi centroid (modus), satu untuk setiap cluster.

2. Alokasikan data ke cluster dengan modusnya terdekat menggunakan persamaan berikut:

$$
d(x, y)=\sum_{j=1}^{r} \in\left(x_{j}, y_{j}\right)
$$

3. Perbarui modus (sebagai centroid) dari setiap cluster dengan nilai kategori yang paling sering muncul pada setiap cluster.

4. Ulangi langkah 2 dan 3 selama masih memenuhi syarat a. Masih ada data yang berpindah cluster, atau

b. Perubahan nilai fungsi obyektif masih di bawah ambang batas yang ditentukan.

Pada penelitian ini dilakukan beberapa tahapan yang dimulai dari analisa data, penentuan metode, perancangan metode k-means, perancangan metode $\mathrm{k}$-modes, proses perhitungan data dan analisa hasil.

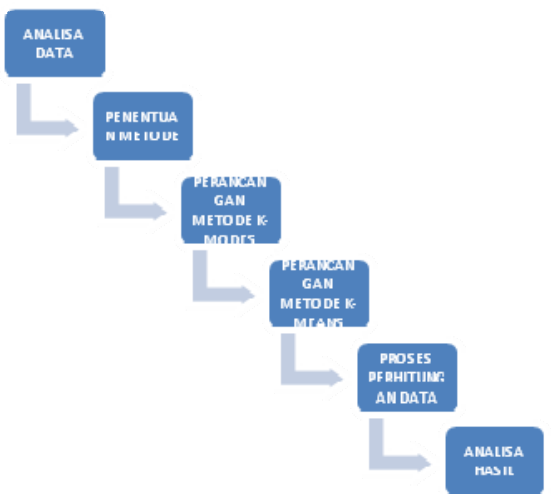

Gambar 2. Metodologi Penelitian

Keterangan gambar: berikut:

Pada penelitian ini dilakukan langkah sebagai

1. Analisa Data dilakukan untuk mengetahui berapa banyak data transaksi, jenis barang dan harga dari barang.

2. Penentuan Metode dilakukan untuk mengetahui metode yang sesuai untuk masalah tersebut.

3. Perancangan metode K-means untuk membuat proses perhitungan dengan metode tersebut.

4. Perancangan metode K-modes untuk membuat proses perhitungan dengan metode tersebut.

5. Proses perhitungan dilakukan untuk menguji apakah metode yang digunakan sudah sesuai dan nilai yang dihasilkan sesuai dengan yang diharapkan.

\section{HASIL DAN PEMBAHASAN}

Berikut ini adalah hal-hal yang perlu disiapkan untuk proses implementasi yaitu perangkat keras (hardware), perangkat lunak (software) dan bahan pengujian yang penulis menggunakan dalam pendekatan Model Clustering Data Mining Menggunakan Metode K-Means Dan K-Modes Dalam Menentukan Himpunan Pemesanan Bahan Tekstil (Studi Kasus: UD.HO KIKU).

\section{a. Persiapan Pengujian}

1) Alat

Dalam melakukan penelitian ini, digunakan alat yang terdiri dari perangkat keras dan perangkat lunak.

Dari sisi perangkat keras, spesifikasi yang digunakan sebagai berikut:

1. Processor Intel Core i5

2. RAM $1 \mathrm{~GB}$

3. VGA $1 \mathrm{~GB}$ 


\section{Harddisk $500 \mathrm{~GB}$ \\ 5. DVD RW $50 \times$ \\ 6. LCD Monitor 14" \\ 7. Mouse, Keyboard}

Dari sisi perangkat lunak, spesifikasi yang digunakan sebagai berikut:

1. Sistem Operasi Windows 7 Service Pack 1

2. Matlab R2010a

3. Microsoft Office 2007

\section{2) Bahan}

Adapun bahan yang digunakan dalam penelitian ini adalah Data rekapitulasi Jumlah Kebutuhan dan Pemakaian Bahan Baku Tekstil 2011 s.d 2014

\section{b. Skenario Pengujian}

Pada proses skenario pengujian menggunakan metode black box testing, ini bertujuan untuk menunjukkan fungsi perangkat lunak tentang cara berjalannya aplikasi sitem yang telah dibuat, apakah data keluaran telah berjalan sebagaimana yang diharapkan sesuai dengan perancangan. Metode pengujian black box ini merupakan metode pengujian dengan program kasus pengujian yang berbasis spesifikasi, dan pengujian dapat dilakukan pada saat proses pengembangan sistem.

Dalam proses pengujian terhadap sebuah perangkat lunak harus ditetapkan kategori keberhasilan dalam setiap kasus yang diuji. Skenario pengujian dapat dilihat pada tabel 5.1.

Tabel 1. Skenario Pengujian

\begin{tabular}{|c|c|c|c|}
\hline No & $\begin{array}{l}\text { Antar } \\
\text { muka } \\
\text { yang diuji }\end{array}$ & $\begin{array}{l}\text { Cara } \\
\text { pengujian }\end{array}$ & $\begin{array}{l}\text { Hasil yang } \\
\text { diharapkan }\end{array}$ \\
\hline \multirow[b]{2}{*}{1} & \multirow[b]{2}{*}{$\begin{array}{l}\text { Halaman } \\
\text { Depan }\end{array}$} & $\begin{array}{l}\text { Klik } \\
\text { 'Pengolahan } \\
\text { Data' }\end{array}$ & $\begin{array}{l}\text { Tampilan } \\
\text { Halaman Data }\end{array}$ \\
\hline & & Klik 'Keluar' & $\begin{array}{l}\text { Muncul Pesan } \\
\text { Keluar/Tidak jika } \\
\text { dipilih Ya makan } \\
\text { keluar dari } \\
\text { aplikasi }\end{array}$ \\
\hline \multirow{7}{*}{2} & \multirow{7}{*}{$\begin{array}{l}\text { Tampilan } \\
\text { Utama }\end{array}$} & $\begin{array}{l}\text { Klik 'Drop } \\
\text { Down Tahun' }\end{array}$ & $\begin{array}{l}\text { Tampil tahun } \\
\text { pada combobox }\end{array}$ \\
\hline & & $\begin{array}{l}\text { Klik 'Radio } \\
\text { Button Bulan' }\end{array}$ & $\begin{array}{l}\text { Tanda } \\
\text { radiobutton } \\
\text { Bulan terpilih }\end{array}$ \\
\hline & & $\begin{array}{l}\text { Klik 'Load } \\
\text { Data' }\end{array}$ & $\begin{array}{l}\text { Tampil data } \\
\text { sumber pada } \\
\text { tabel }\end{array}$ \\
\hline & & $\begin{array}{l}\text { Isi 'Angka } \\
\text { Cluster' }\end{array}$ & $\begin{array}{l}\text { Tampil Angka } \\
\text { pada Texboxt } \\
\text { Cluster }\end{array}$ \\
\hline & & $\begin{array}{l}\text { Klik 'Proses } \\
\text { Cluster' }\end{array}$ & $\begin{array}{l}\text { Tampil data } \\
\text { cluster pada } \\
\text { tabel }\end{array}$ \\
\hline & & $\begin{array}{l}\text { Klik 'Data } \\
\text { Sumber' }\end{array}$ & $\begin{array}{l}\text { Tampil data } \\
\text { sumber hasil } \\
\text { proses pada } \\
\text { table }\end{array}$ \\
\hline & & $\begin{array}{l}\text { Klik } \\
\text { 'Perhitungan } \\
\text { KMeans' }\end{array}$ & $\begin{array}{l}\text { Tampil Hasil } \\
\text { perhitungan } \\
\text { KMeans Setelah } \\
\text { proses cluster } \\
\text { pada tabel. }\end{array}$ \\
\hline
\end{tabular}

\begin{tabular}{|c|c|c|c|}
\hline & & $\begin{array}{l}\text { Klik menu } \\
\text { 'Perhitungan } \\
\text { KModes' }\end{array}$ & $\begin{array}{l}\text { Tampil Hasil } \\
\text { Perhitungan } \\
\text { KModes setelah } \\
\text { proses Cluster } \\
\text { pada table }\end{array}$ \\
\hline & & $\begin{array}{l}\text { Klik menu } \\
\text { 'Cluster' }\end{array}$ & $\begin{array}{l}\text { Tampil hasil } \\
\text { cluster hasil } \\
\text { proses pada } \\
\text { table }\end{array}$ \\
\hline & & $\begin{array}{l}\text { Klik menu } \\
\text { 'Grafik' }\end{array}$ & $\begin{array}{l}\text { Tampil Grafik } \\
\text { perbandingan } \\
\text { hasil cluster }\end{array}$ \\
\hline & & $\begin{array}{l}\text { Klik Menu } \\
\text { 'Kesimpulan' }\end{array}$ & $\begin{array}{l}\text { Tampil } \\
\text { kesimpulan } \\
\text { prioritas bahan } \\
\text { tekstil }\end{array}$ \\
\hline & & $\begin{array}{l}\text { Klik Menu } \\
\text { 'Export to } \\
\text { Excel' }\end{array}$ & $\begin{array}{l}\text { Data yang tampil } \\
\text { di table disimpan } \\
\text { ke current folder } \\
\text { matlab sebagai } \\
\text { file 'output.xls' }\end{array}$ \\
\hline & & $\begin{array}{l}\text { Klik Menu } \\
\text { 'Back' }\end{array}$ & $\begin{array}{l}\text { Kembali ke Form } \\
\text { Utama }\end{array}$ \\
\hline
\end{tabular}

\section{c. Pengujian}

Pada pengujian ini penulis menggunakan Matlab R2010a. Adapun tahapan pengujiannya adalah sebagai berikut:

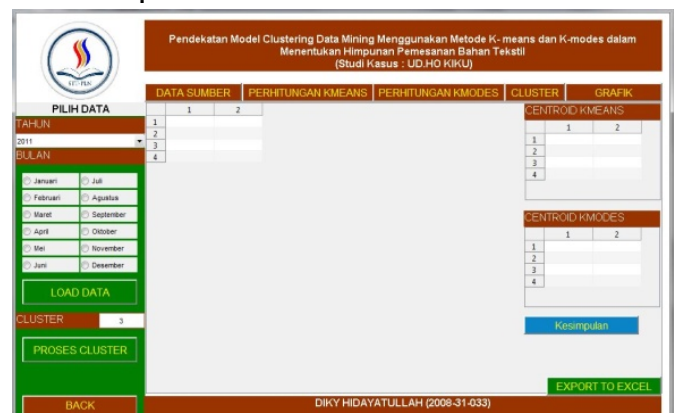

Gambar 2. Form Pengolahan Data

Pada halaman ini ditampilkan semua menu yang ada berikut tabel penampung data hasil proses.

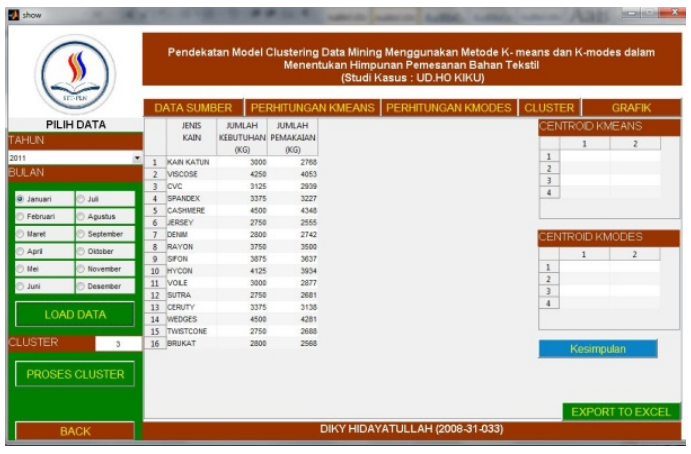

Gambar 3. Form Pengolahan Data Menu Data Sumber

Pada gambar 5.4 adalah hasil setelah tombol Load Data ditekan. Pada table ditampilkan hasil data sumber untuk bulan Januari tahun 2011. 


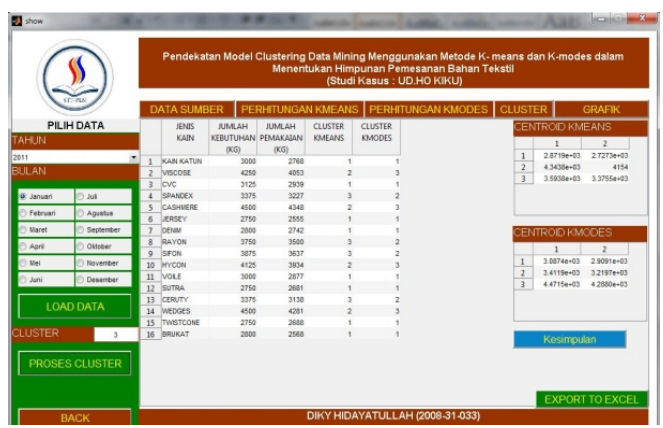

Gambar 4. Form Pengolahan Data Menu Proses Cluster

Pada halaman ini, ditampilkan hasil proses cluster dengan 3 centroid/titik pusat. Hasil cluster ini didapat setelah melalui perhitungan jarak terdekat dari titik $X, Y$ dimana $X$ adalah Kebutuhan dan $Y$ adalah Pemakaian. Hasil perhitungan Kmeans diperlihatkan pada gambar 5.5 , sedangkan hasil perhitungan KModes diperlihatkan pada gambar 5.6 .

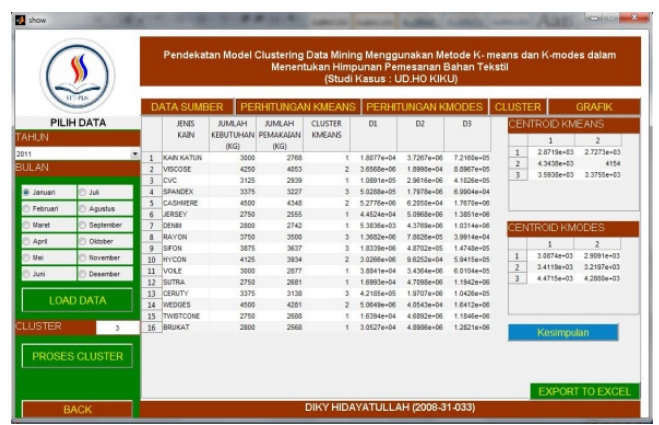

Gambar 5. Form Pengolahan Data Menu Perhitungan KMeans

D1 menyatakan jarak yang diukur dari titik uji ke centroid ke-1, D2 menyatakan jarak yang diukur dari titik uji ke centroid ke-2, dst. Semakin kecil jarak yang didapat maka semakin besar kemungkinan titik tersebut masuk dalam cluster terdekat.

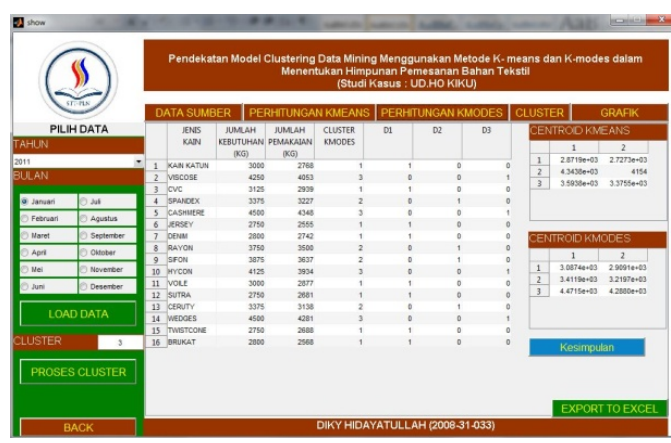

Gambar 6. Form Pengolahan Data Menu Perhitungan KModes

Pada halaman ini, nilai jarak D1 dinyatakan dalam logika. Jika bernilai 1 maka dinyatakan frekuensi kemunculan terhadap titik pusat ke-1 memiliki probabilitas tertinggi, sebaliknya nilai 0 menyatakan bahwa titik uji jauh dari titik pusatnya.

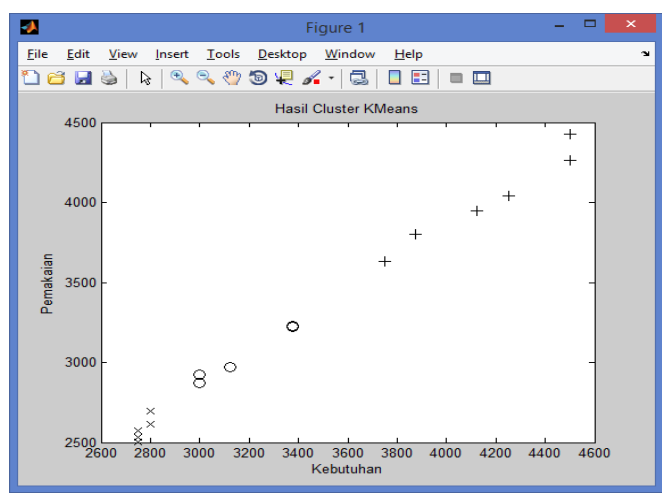

Gambar 7. Form Pengolahan Data Grafik KMeans

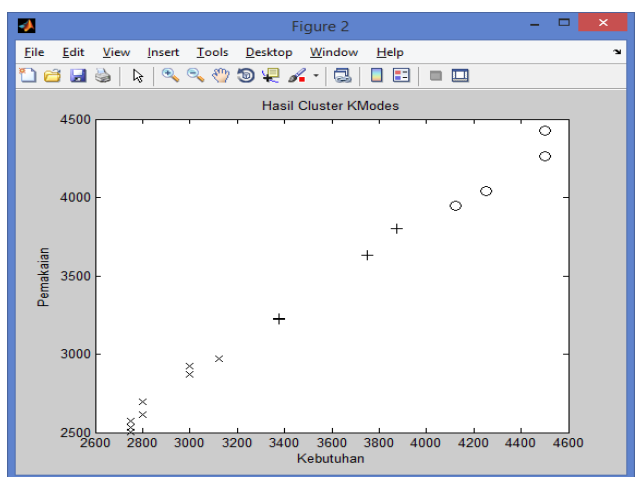

Gambar 8. Form Pengolahan Data Grafik KModes

\section{d. Hasil Pengujian}

Setelah melakukan serangkaian proses pengujian yang sesuai dengan skenario pengujian, maka penulis melakukan proses pengisian pada tabel 5.1 yang sebelumnya pada proses skenario pengujian belum terisi status atau hasil dari pengujian tersebut. Langkah ini adalah penting untuk mengetahui seberapa besar penyimpanan data kesalahan yang disebabkan oleh programmer dalam menulis syntaks program. Pada tabel 5.2 merupakan tabel hasil pengujian sistem.

Tabel 2. Hasil Pengujian

\begin{tabular}{|c|c|c|c|c|}
\hline No & $\begin{array}{l}\text { Antar } \\
\text { muka } \\
\text { yang } \\
\text { diuji }\end{array}$ & $\begin{array}{l}\text { Cara } \\
\text { pengujian }\end{array}$ & $\begin{array}{l}\text { Hasil yang } \\
\text { diharapkan }\end{array}$ & Status \\
\hline \multirow[b]{2}{*}{1} & \multirow[b]{2}{*}{$\begin{array}{l}\text { Halaman } \\
\text { Depan }\end{array}$} & $\begin{array}{l}\text { Klik } \\
\text { 'Pengolahan } \\
\text { Data' }\end{array}$ & $\begin{array}{l}\text { Tampilan } \\
\text { Halaman Data }\end{array}$ & Sesuai \\
\hline & & Klik ‘Keluar' & $\begin{array}{l}\text { Muncul Pesan } \\
\text { Keluar/Tidak jika } \\
\text { dipilih Ya makan } \\
\text { keluar dari } \\
\text { aplikasi }\end{array}$ & Sesuai \\
\hline \multirow{4}{*}{2} & \multirow{4}{*}{$\begin{array}{l}\text { Tampilan } \\
\text { Utama }\end{array}$} & $\begin{array}{l}\text { Klik 'Drop } \\
\text { Down } \\
\text { Tahun' }\end{array}$ & $\begin{array}{l}\text { Tampil tahun } \\
\text { pada combobox }\end{array}$ & Sesuai \\
\hline & & $\begin{array}{l}\text { Klik 'Radio } \\
\text { Button } \\
\text { Bulan' } \\
\end{array}$ & $\begin{array}{l}\text { Tanda } \\
\text { radiobutton Bulan } \\
\text { terpilih }\end{array}$ & Sesuai \\
\hline & & $\begin{array}{l}\text { Klik 'Load } \\
\text { Data' }\end{array}$ & $\begin{array}{l}\text { Tampil data } \\
\text { sumber pada } \\
\text { tabel }\end{array}$ & Sesuai \\
\hline & & $\begin{array}{l}\text { Isi 'Angka } \\
\text { Cluster' }\end{array}$ & $\begin{array}{l}\text { Tampil Angka } \\
\text { pada Texboxt } \\
\text { Cluster } \\
\end{array}$ & Sesuai \\
\hline
\end{tabular}




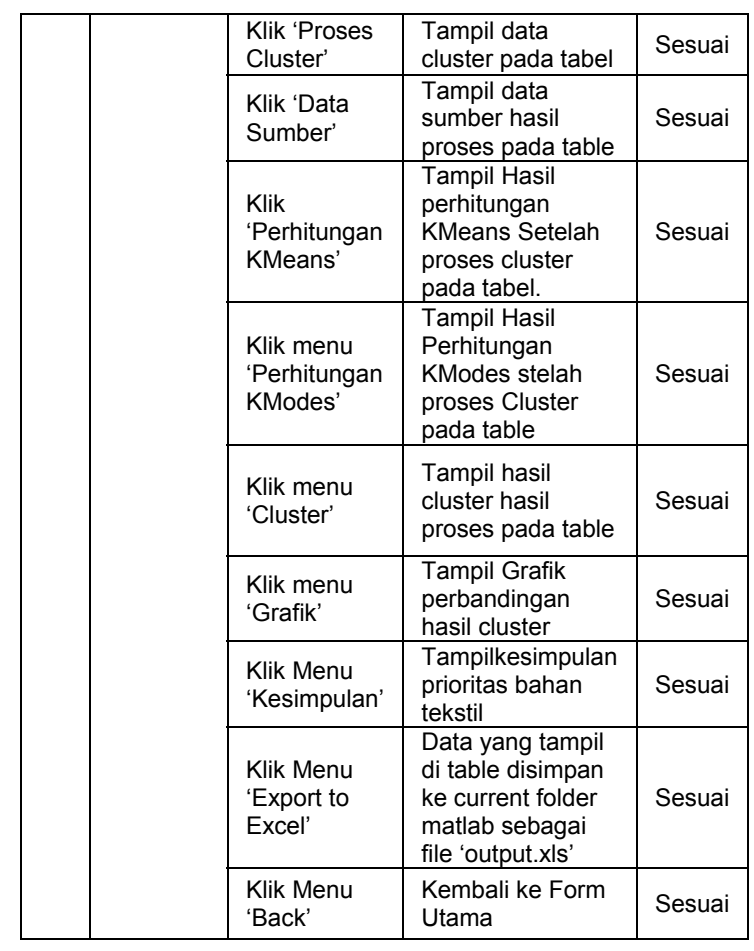

\section{Pembahasan}

Pada pembahasan dari pengujian sebagai berikut:

1. Kesimpulan prioritas kebutuhan pada tahun 2011 adalah sebagai berikut:

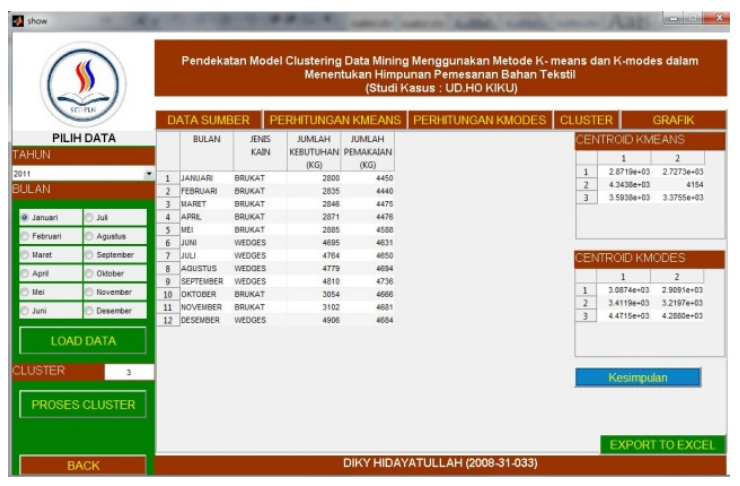

2. Kesimpulan prioritas kebutuhan pada tahun 2012 adalah sebagai berikut:

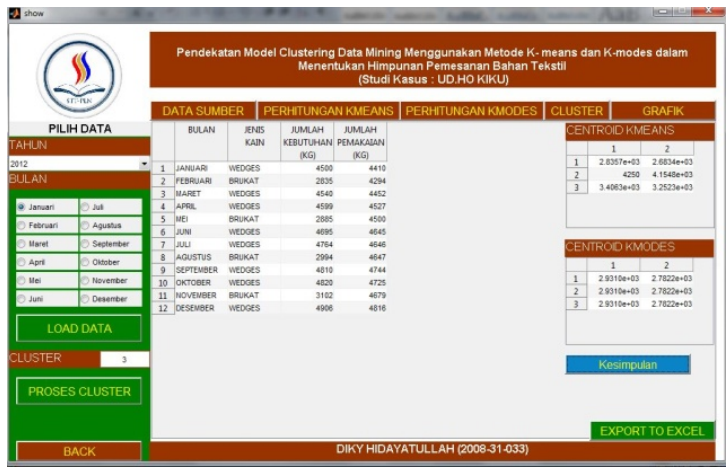

3. Kesimpulan prioritas kebutuhan pada tahun 2013 adalah sebagai berikut:

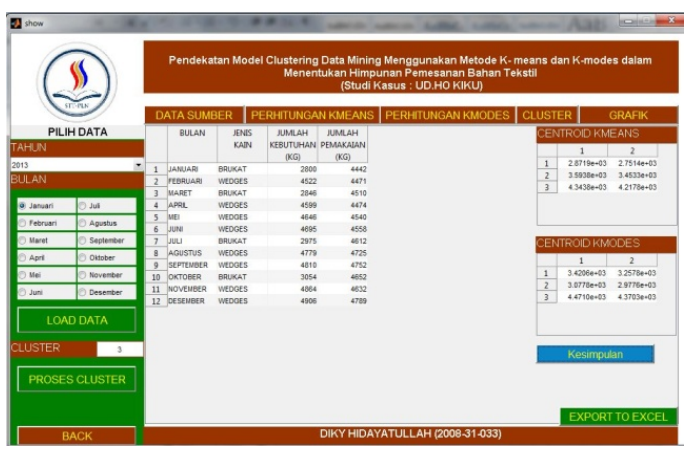

4. Kesimpulan prioritas kebutuhan pada tahun 2014 adalah sebagai berikut:

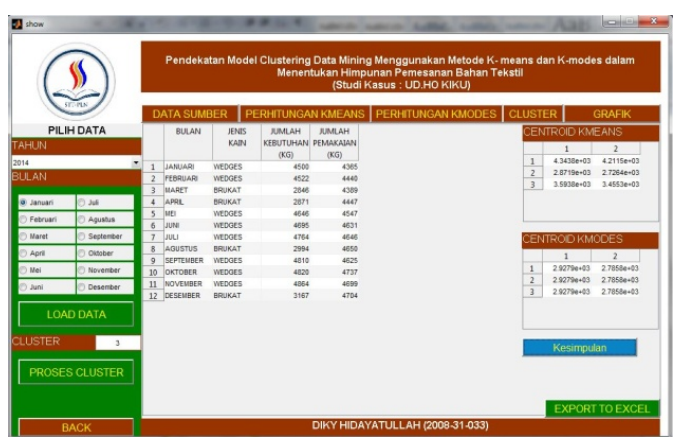

\section{DAFTAR PUSTAKA}

1. Alfatta, Hanif. 2007. Analisis dan Perancangan Sistem Informasi. Penerbit Andi, Yogyakarta.

2. Berson, A., Smith, S., dan Thearling, K. (2000). Building Data Mining Application for CRM. New York: The McGraw-Hill Companies, Inc

3. Connolly (2002, p1115). Statistics, Data Mining, and Machine Learning in Astronomy: A Practical Python Guide for the Analysis of Survey Data. USA: Pearson Education Limited.

4. Copeland, Lee, 2006, State Transition Diagrams, Testing UML Model, Part 4, www.stickyminds.com

5. McFadden, Fred R. dan Jeffrey $A$. Hoffer.1991. Database Management. Benjamin/Cummings Pub. Co.

6. Berson, Alex, dkk. 2000. Building Data Mining Applications for CRM. McGraw-Hill

7. Eko Prasetyo, 2014. Data Mining, Mengolah Data Menjadi Informasi Menggunakan Matlab. Yogyakarta: Andi

8. Susanto, Sanidan Dedy Suryadi.2010. Pengantar Data Mining.Yogyakarta: Andi

9. Sahid. 2006. Panduan Praktis Matlab. Yogyakarta: Andi.

10. Mathworks.www.Mathworks.com.16Januari 2015

11. Membuat nilai acak di microsoft excel.http:// hadi.web.id/2009/02/membuat-nilai-acak-dimicrosoft-excel.html.2 Desember 2014

12. Teknik penarikan sampel acak sederhana. http://www.slideshare.net/guns12380/teknikpenarikan-sampel-acaksederhana.31Desember 2014 